\title{
A Study Of Motivation In Business Start-Ups Among Malay Entrepreneurs
}

Ahmad Zaki Bin Hj. Ismail, International Islamic University Malaysia

Mohd Fadzely Bin Mohd Zain, International Islamic University Malaysia

Elsadig Musa Ahmed, (Email: elsadigmusa@yahoo.com), Multimedia University Malaysia)

\begin{abstract}
The effect of entrepreneurships in developing economies was studied widely in prior researches, since entrepreneurs contribute significantly in economics development. The purpose of this study is to explore and understand Malay entrepreneurs in the eastern region of Peninsular Malaysia; who are the majority ethnic group in the area. The study is concentrated on the motivation factors that influenced their decision to start up new businesses. This study also examined problems faced by those entrepreneurs, both during start up stage and during present operation. Basic variables on entrepreneurs' background and their business characteristics were taken into account.
\end{abstract}

The motivational factors were examined using a modified model from Scheinberg and MacMillan. The primary data collections methods were structured interviews and surveys. "Statistical Package for the Social Science" (SPSS) was used in analyzing the data. Frequency and descriptive analysis were used to examine the basic variables and problems facing the entrepreneurs. Factor analysis was applied to determine the motivation factors. In addition, ANOVA and MANOVA were used to test the hypotheses developed.

The study shows that majority of Malay entrepreneurs are male. One third of the entrepreneurs are well educated up to the tertiary level. Almost all of them are married and has worked in three different fields prior to starting their own business. They were involved in operating small business for others, worked as Government servants or in private firms. A majority of their parents operate their own business. Major problems in conducting business lies in stiff competition from others and also insufficient initial capital. Seven motivational factors were determined to have influenced Malay entrepreneurs to start up business. The most influential factors are spiritual liability, personal development and satisfaction, and financial security. Other important factors are opportunities, freedom, accommodation and escapism. Meanwhile, five hypotheses were developed for this study. The result shows that the level of education of entrepreneurs is significant with reference to the motivational factors. On the other hand, gender, previous work and parents' occupation are of no significance. However, combination of gender and level of education showed certain level of significance with reference to their motivational factors.

\section{INTRODUCTION}

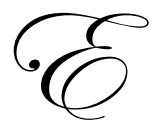

ntrepreneurship activities help develops a country's economy and social wellness of one particular society. Entrepreneurs have helped to put up many choices of products and services in the market for consumers to choose from. New firms emerge with new or better products or services to challenge existing competition; therefore creating a dynamic marketplace. During the Seventh Malaysia Plan, which covers the period of 1996 to 2000, the Government of Malaysia has strongly emphasized on the development of small-scale industries (SMIs), especially the one that can help to develop the domestic market (Seventh Malaysia Plan 1996).

In the second assembly of the National Economic Council of Malaysia (MAPEN II 2001), the council has recognized the importance of restructuring with adequate entrepreneurs and potential organizations in order to develop 
a successful Malay (from the Bumiputra group) community in the country. Various programs were introduced to help develop existing and new businesses. The Government also encourages wider involvement of Malays in new high technology sectors, such as the information technology (MAPEN II 2001).

The new businesses created have been the new source of new jobs in the economy (Zimmerer \& Scarborough 1996). According to a study made in 1992 by the National Foundation for Women Business Owners (NFWBO), one quarter of the American work force is hired by the businesses owned by women, which only represents $38 \%$ of total business ownership in the United States (McKay 2001). Herron and Sapienza (1992) found that many of the previous researches attempted to relate traits of the entrepreneurs to new venture creation have failed to demonstrate definitive linkage. However, Shaver and Scott (1991) have argued that traits approach would be a productive perspective in studying entrepreneurships.

In Malaysia, industrial enterprises are divided into four main categories. They are the Tiny-scale Industries (TSI), Small-scale Industries (SSI), Medium-scale Industries (MSI) and Large-scale Industries (LSI). However, this study only concentrates on companies that fall under the category of Small and Medium Industries (SMIs). SMI is defined as a company that consists of 150 employees and below and yearly sales turnover of less than RM 25 million (Abdul Halim 1998).

The main purpose of this paper is to study and analyze Malay entrepreneurs in the eastern region of Peninsular Malaysia. The study focused on the perspective of motivational factors that led the entrepreneurs to initiate start up activities. Furthermore, data on a few independent variables, such as the demographic data, spiritual factor and the educational background of the Malay entrepreneurs was analyzed in order to establish if there is any relation with their motivational factors. The results would help to gain better understanding of Malay entrepreneurs in Malaysia, and the effect on an ethnic group that has always put the career in entrepreneurships as their last resort (Yeb Puteh 1985). The motivational factors and the independent variables of the entrepreneurs would contribute to clear understanding of the differences of Malay entrepreneurs, compared to other ethnic groups such as the Chinese and the Indians.

\section{METHODOLOGY AND ESTIMATION TECHNIQUES}

This section describes methods in collecting and processing data that were used in this study. The data from entrepreneurs was collected in several areas, including the entrepreneurs' background, business information, problems faced by them during start up activities, current problems and finally, the entrepreneurs' motivational factor that lead them to initiate start up.

The research was conducted using a 5-page questionnaire, which was a modification to the questionnaires by Wang (1999). The data were collected using two methods. One was by conducting structured interviews and second, by conducting surveys. Personal visit and telephone follow up were done to increase response rates in the surveys. The questionnaire was designed for Malay entrepreneurs who are currently residing and operating in the State of Kelantan, and in the district of Besut, State of Terengganu. The questions were designed in ways, which can be used to distinguish between the entrepreneurs and the small-business owners. The questionnaires were distributed randomly in all major cities and towns in the two states, which are around Kota Bharu, Pasir Puteh, Machang, Tanah Merah and Besut. The district of Pasir Mas, Tumpat and Rantau Panjang were not included to prevent the data from the influence of Siamese born entrepreneurs. The information obtained was then analyzed using frequency analysis. This method was applied for data obtained in Parts A and B of the questionnaire. The frequency analysis was used to describe the many types of variables, which were related to the entrepreneurs. The studies provide certain ability to explain and characterize certain characteristics of variables.

Secondly, descriptive study was used to analyze problems faced by the entrepreneurs. It involved data obtained in Part $\mathrm{C}$ of the questionnaire. Descriptive studies helped to rank the problems according to the most occurring to the least. It was done by calculating the mean value of every problematic issue facing the entrepreneurs. Then, another descriptive study was carried out on the method of solution taken by entrepreneurs in solving their business problems. 
Finally, inferential statistics were employed in analyzing the data. The information obtained from the questionnaire were grouped and coded before further analyses with the appropriate statistical techniques were used. The techniques used were factor analysis, ANOVA (Analysis of Variance) and MANOVA (Multiple Analysis of Variance). The results were used to explain the relationships involved in hypothesis studies.

\section{Results and Discussion}

The purpose of this part is to report on the data gathered and to present summary and discussion of the statistical analysis done on these data. The part is divided into several sections. The first section is on the reliability test of the data. The second section is the background information of the respondents. The third section is about the business information. The fourth section is the description on the problems facing those entrepreneurs. The final section is the factor analysis of motivational factors and several hypothesis testing.

\section{Reliability Test}

Reliability test was concerned with the degree to which a measurement was free of random or unstable error. In this study, all 20 items of business problems and method of solutions in Part $\mathrm{C}$ and all 44 items of motivational factors were included in determining the Cronbach's Alpha coefficient value. After calculation, the result revealed a value of 0.8989 , which suggests a fair level of internal consistency within the data collected, since the acceptable value is 0.70 or higher (McKinnis et al. 2001).

\section{Entrepreneurs' Background}

In Part A of the questionnaire, respondents were asked roughly about their background. Among the questions asked were related to education level, gender, age, marital status, previous job, and parents' employment. The summaries of the findings are presented below.

\section{Gender}

From the frequency analysis carried out on the data, $69 \%$ of the respondents were male and another $31 \%$ were female. Even though there were many women small business owners located in the area of studies, not many were pursuing to become successful entrepreneurs. Many of them were conducting business to earn a living for the family and have no plan to expand further. They were only satisfied if the money earned from their daily business was enough to cover their family monthly expenses. The situation was different when compared to the male businessmen. The male businessmen tend to think further ahead in expanding their businesses; as a result, they were able to rent large shop lots to carry out their businesses. They were also able to open up branches in several other places within the state. The full result of the tabulation of gender is as shown in Table B-2.1 in Appendix B. The result is similar to the findings carried out by Wang (1999) for Chinese entrepreneurs in the northern state of Peninsular Malaysia. The gender distribution was $65.1 \%$ male and $34.9 \%$ female.

\section{Level of Education}

The distribution of the level of education of the respondents is as shown in Table B-2.2 in Appendix B. The percentile amount can be better explained in the pie chart below. From all 72 respondents, $38 \%$ were graduates from tertiary level of education. They were people with certain skill or knowledge in certain fields. These skills and knowledge give them a sense of confidence in providing good services or products to the market. The result is somewhat different from a study made on selected Bumiputra SMIs in Malaysia (Hj Ismail 1998). The study was done throughout the eastern, northern, and central regions of Peninsular Malaysia. The result showed that more than half $(53 \%)$ of respondents are graduates and the other $47 \%$ are non-graduates.

Meanwhile, in this study, another $62 \%$ were those who were secondary or primary school leavers. Some of them started their own businesses as a result from their frustration in finding jobs with reasonable pay. According to them, with their education level, the only way for them to have a comfortable life was by operating own businesses. 


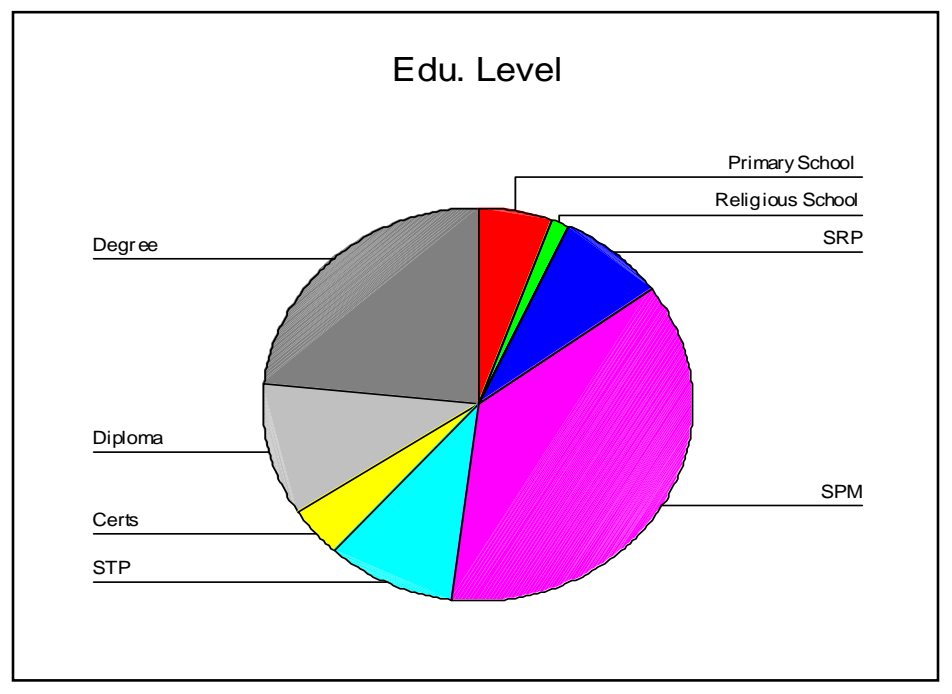

Figure 1: Education Level of Malay Entrepreneurs

Status

Most of the entrepreneurs who took part in the studies were married. Only $15 \%$ of them were either still single or widowers. Almost $85 \%$ were married and only $8 \%$ were still single.

\section{Previous Job}

The tabulation on the previous job from the respondents has shown that they came from different work background. The tabulation seems evenly between three different categories, which were small business, civil servants and private firms. Even though the largest percentage (33\%) of the entrepreneurs have experience in doing small business in their previous job, the value of percentage of the other two groups is not so much of a difference. As a result, based on this initial observation, the type of experience from the previous job does not show any significant influence on decision to start up their business.

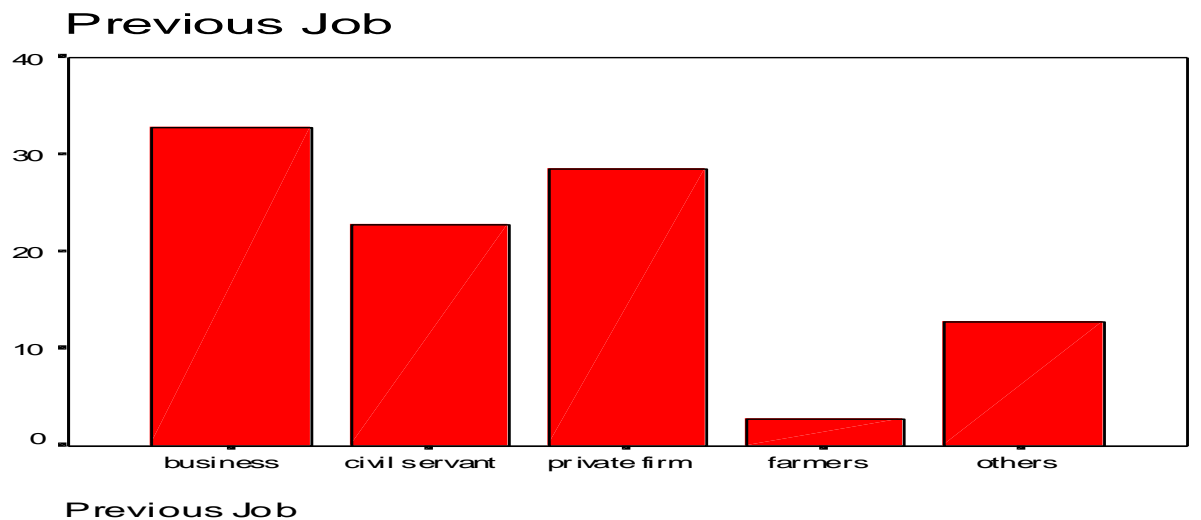

Figure 2: Previous Job of Malay Entrepreneurs 
Parents' Job

Parents' occupation has shown certain significance in influencing their children in their future job. Almost $40 \%$ of the respondents came from family with business background. A few of them inherit businesses from their own parents; meanwhile others have possessed strong interest in operating own businesses because of the influence from the parents. Many of the respondents admitted that by having parents with business background, it is easier for them to understand the struggle. These results however differ from the finding recorded by Wang (1999). In his study of Chinese entrepreneurs, more than $75 \%$ of the respondents already acquired certain amount of experience in managing and operating small business.

\section{Business Information}

Part B of the questionnaires was concerned about the business information of the respondents. Among the questions asked were concerning type of business, method of founding, number of employees and their main source of capital. The explanation was given in the following sections.

Business Type

The business type was divided into five different categories; food, manufacturing, groceries, services and construction. For those who operate businesses, which do not fall into these five categories, the answer was put as 'others'. From the results obtained, major portion of the respondents $(42 \%)$ was conducting services type of businesses. Second major group of the respondents were involved in groceries, which was $29 \%$.

\section{Method of Founding}

Most of the respondents (63\%) founded the organization on their own. From the reply, it was understood during the interview that they were not willing to open up business by sharing with others to avoid difficulties in the future. By totally owning the business, they can have total freedom to steer the organization in accordance to their own vision and capabilities. However, another $21 \%$ founded their business with partner/partners. The main reason behind it was because of large initial capital required to launch the business. In addition, by having partners, the financial risk can be minimized. Furthermore, partners can provide ideas and additional business contacts to help the business to grow; not to mention skills and specialties. However, according to some of them, by having partners, one has to be more flexible and tolerable, and the most important of all, is trust. Only 10\% of the respondents operating businesses inherited them from their parents. Meanwhile, another $4 \%$ bought them from other people.

\section{Number of Employees}

The number of employees ranged from one to as many as twenty. It depends on the type of businesses operated by the respondents. Normally, businesses, which are of manufacturing and construction types, require many workers. However, for those who operate businesses such as of groceries or services, they do not require many workers. According to a survey released by research bureau EIM, some $90 \%$ of start-ups are one-man operations, and added that, only half of the entrepreneurs aimed to increase staffing level (Het Financieele Dagblad 2002).

\section{Capital Source}

Nearly two third of the respondents launched their business using their own savings as the main source of capital. Even though they still use some other credit facilities from banks or suppliers, the amount was minimal. The reason behind it was to minimize risks, according to them. Since the business was still new, they said, it was better not to borrow a lot, to avoid from being unable to generate enough income to meet the scheduled payments. This was important because the most difficult period of operating own business, as informed by the respondents, was during the first few years after launching. However, they said, when the business become more stable, many have the initiative to borrow substantially from banks in order to increase capital and expand businesses. 
The result is similar to a study carried out by U.S. Census Bureau whereby, out of 17.3 million American businesses, two-thirds of owners started out with no borrowed capital. (Scott 2002) It is also similar to a study carried out by Wang (1999) whereby, two third of the Chinese entrepreneurs in Malaysia also started their business by not taking any loans.

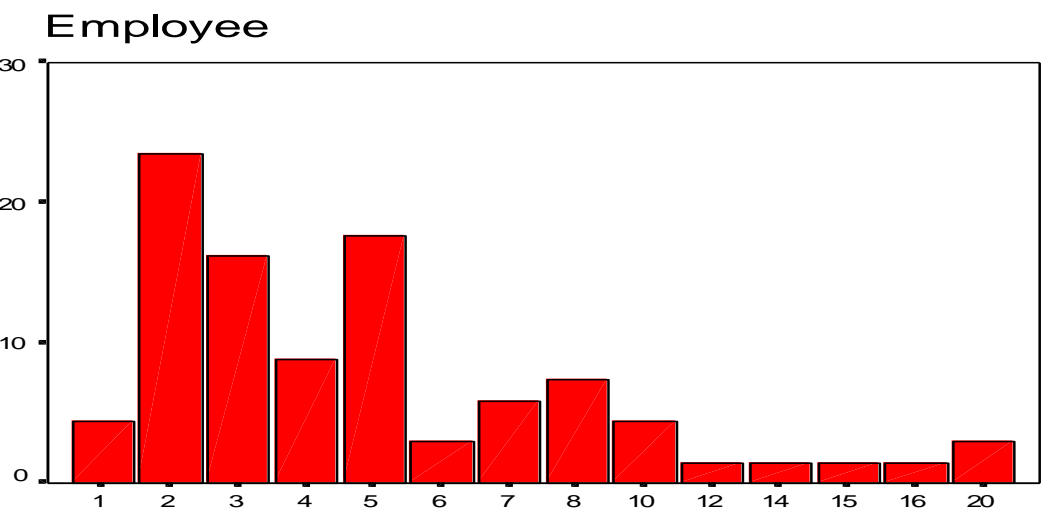

Employee

Figure 3: Number of Employees

\section{Business Problems}

Part $\mathrm{C}$ of the questionnaire was concerned about the business difficulties or problems. The problems might occur during start up, at present or both. Then, the respondents were asked on how they usually solved the problems.

\section{Type of Problems}

For part C, descriptive studies were done on the data collected. The method has ensured a better understanding of the situation. The value of means was calculated, whereby, the closer the mean value to 1 will indicate the more problematic the issue was. Based on the result, most teething problem faced by the entrepreneurs is problem l: stiff competition from other organizations. Other major problems are problem a: initial capital, problem h: financial, problem m: price of raw materials and equipment, and problem d: obtained skill workers. However, most of the entrepreneurs seem to be enjoying enough support from their own family members. They did not encounter many problems in getting licenses or permits from governmental agencies to carry out their business operations. In addition, raw materials seem adequate.

\section{Method of Solutions}

Most of the time, the entrepreneurs only depend on themselves to solve their business problems. The results showed a mean value of 1.27 for own effort, which is the nearest to 1.00 (1.00 indicates that the statement is true). Other support seems to come from parents or family members, and from friends. The result also revealed that not many of the respondents depend on Governmental agencies, private firms or business organizations to help them during their hard time. The value of mean for Government agencies is 4.67, which shows that most entrepreneurs have not turned to Government to help them with their business problems.

\section{Motivational Factors}

Questions for Part D of Motivational Factors were divided into 44 different items. Each item describes the probable reason for the entrepreneurs to initiate start up activities. The respondents were asked to answer, based on the 
rating scale of 5 to 1,5 being "very true" and 1 being "very untrue". However, there were questions from part D where the respondents failed to provide any answer and were asked to leave the answer as blanks.

\section{Factor Analysis}

All the answers were included in the analysis. They were used including the missing value, which were set to be at 0 . A factor analysis was conducted on all of the 44 items. The factor analysis was conducted using the principal component axis technique and the results were rotated using the Varimax rotational method. The method has revealed very interesting results on factors that influenced entrepreneurs to initiate start up activities. The method helped to determine items, which should be included or excluded in determining factors. Items that were retained then individually grouped or loaded into components or factors, which will then be analyzed. The main criterion used for retention of an item in a factor was a minimum value of 0.5 factors loading (coefficient of correlation). From the initial results, several items or variables were dropped based on several other criteria. Items that were loaded into more than one factor were discarded. No factors with less than two distinct motivation items were retained.

\section{Type of Motivation Factors}

In summary, the most influential factor that motivated Malay entrepreneurs to start their own business were listed in the Table 1, which were arranged from the most influential factor to the least.

Table1: Motivational Factors of Malay Entrepreneurs

\begin{tabular}{|l|l|}
\hline & Motivation Factor \\
\hline 1 & Spiritual Liability \\
\hline 2 & Satisfaction and Self-Development \\
\hline 3 & Wealth \\
\hline 4 & Opportunities \\
\hline 5 & Freedom \\
\hline 6 & Recognition \\
\hline 7 & Escapism \\
\hline
\end{tabular}

The results of the 7-factor model explained 53.671 percent of the total variance. This result is encouraging when considering the large number of variables/items taken into account, which were 31 out of originally 44 . In summary, the most influential factor that motivated male Malay entrepreneurs to start their own business were listed in the Table 2, which were arranged from the most influential factor to the least.

Table2: Motivational Factors of Male Malay Entrepreneurs

\begin{tabular}{|l|l|}
\hline & Motivation Factor \\
\hline 1 & Spiritual Liability \\
\hline 2 & Self-Development \\
\hline 3 & Opportunities \\
\hline 4 & Wealth \\
\hline 5 & Accommodation \\
\hline 6 & Escapism \\
\hline 7 & Freedom \\
\hline
\end{tabular}

The results of the 7-factor model explained 45.012 percent of the total variance. This result is encouraging when considering the large number of variables/items taken into account, which were 26 out of originally 44 . In summary, the most influential factor that motivated female Malay entrepreneurs to start their own business are listed in the table below, which were arranged from the most influential factor to the least. 
Table 3: Motivational Factors of Female Malay Entrepreneurs

\begin{tabular}{|l|l|}
\hline & Motivation Factor \\
\hline 1 & Financial Security \\
\hline 2 & Self-Development \\
\hline 3 & Accommodation \\
\hline 4 & Opportunities \\
\hline 5 & Escapism \\
\hline 6 & Recognition \\
\hline 7 & Facilitation \\
\hline
\end{tabular}

\section{Test Of Hypotheses}

Hypothesis 1: The motivational factors that drive entrepreneurs to start up a business differ in gender.

ANOVA was performed to see if gender has a significant effect on the motivational factors that influenced entrepreneurs to initiate start up activities. Even though factor analysis in the previous section showed that there are some differences, another test using ANOVA is necessary to determine the significance. From the test, the result has indicated that the degree of freedom between groups is 1 and the degree of freedom within groups is 69 . From the schedule of value for 0.05 significance level of " $\mathrm{f}$ ", the result came out to be 3.92. In this case, there are no significant differences in the mean motivation factors of entrepreneurs in gender. The value of " $\mathrm{f}$ " from the test all falls below the value of 3.92. Thus, null hypothesis is accepted, which means from the data sample calculated there is no significant difference of motivational factors of entrepreneurs based on gender.

Hypothesis 2: The motivational factors that drive entrepreneurs to start up a business differ in education level.

ANOVA was also performed to determine whether there are differences between motivational factors of entrepreneurs based on their level of education. From the schedule, " $\mathrm{f}$ " for 0.05 significance level is $(\mathrm{df}=7,65)=$ 2.163 Factor 7 revealed that the value of "f" is exceeding the acceptable value of 2.163. Therefore, alternate hypothesis is accepted, whereby, motivational factors of entrepreneurs are different in their own education level. According to a study made by Hofer and Sandberg (1987), educational level of entrepreneurs has a very strong influence on entrepreneurs. The result from this study also revealed the same manner. Hence, it is proven that, level of education will result in different factors influencing entrepreneurs to initiate start up activities.

Hypothesis 3: The motivational factors that drive entrepreneurs to start up a business differ based on previous working experience.

ANOVA was performed to see if previous job can influence entrepreneurs' motivational factors to initiate own business. From the schedule, "f" for 0.05 significance level is $(\mathrm{df}=4,65)=2.523$. The calculations revealed that all the value of "f" for each motivational factor fell within the acceptance range in 0.05 significance level values. Therefore, null hypothesis is accepted. Motivational factors for entrepreneurs are not differing based on their previous job.

Hypothesis 4: The motivational factors that drive entrepreneurs to start up a business differ based on parents' occupations.

ANOVA was again performed to determine the value of "f" for this hypothesis. From the schedule, "f "for 0.05 significance level is $(\mathrm{df}=3,65)=2.753$. The result revealed that all the values of " $\mathrm{f}$ " fall within the acceptable range in 0.05 significance level values. Therefore, null hypothesis is accepted. There are no significant differences between motivational factors of entrepreneurs based on their parents' occupation. In other words, parents occupations do not significantly influenced entrepreneurs to operate own businesses. 
Hypothesis 5: The motivational factors that drive entrepreneurs to start up business differ in gender and level of education.

In testing the fifth hypothesis, MANOVA was used. The reason behind it was the test requires two independent variables, which are gender and level of education. In the previous test, hypothesis 1: The motivational factors that drive entrepreneurs to start up a business differ in gender; the result revealed that null hypothesis is accepted. This means that there are no significant differences between motivational factors to initiate start up in gender. However in hypothesis 2: The motivational factors that drive entrepreneurs to start up a business differ in education level, alternate hypothesis is accepted. It reveals that there are certain differences in motivational factors in their level of education.

So, the purpose of hypothesis 5 is to determine whether motivational factors of entrepreneurs differ or not in both gender and level of education. From the schedule, "f" for 0.05 significance level is $(\mathrm{df}=5,50)=2.41$. Based on the results, it reveals that the value of "f" fell outside the acceptable value of 0.05 significance level values. Therefore, alternate hypothesis is accepted. Motivational factors of entrepreneurs to initiate start up are differences in gender and levels of education of the entrepreneurs.

\section{CONCLUSION}

This study found that the majority of Malay entrepreneurs are males (two out of three). Most of them have completed their study to at least, secondary level of education. One out of three of them were entrepreneurs with tertiary level of education. Majority of Malay entrepreneurs is married. They came from three different sectors of job prior to becoming an entrepreneur. They used to be small business owners, government servants or employees in private firms. Almost half of the entrepreneurs came from family with business background. It explains part of the reasons of their own career choice. Many of the Malay entrepreneurs are involved in the services industry. Almost two third of the organizations of these Malay entrepreneurs were founded alone by themselves. Another one fifth was founded with a partner or partners. Many of the Malay entrepreneurs initiated their own venture using their own savings as the main portion of their initial capital. Only one-fourth used bank loans as the main source of initial capital, meanwhile another $10 \%$ got them from their family members.

The main problem faced by the Malay entrepreneurs is the stiff competition from others. Another problem was the inability to obtain initial capital to finance their operations. Furthermore, there seems to be shortage of skilled workers available for these entrepreneurs. Most of the Malay entrepreneurs relied on themselves to solve their business problems. However, some of them sought the help of parents, family members or business contacts to solve their problems. Not many refer their problems to government agencies, business associations or privately owned agencies.

This study concludes that the sense of liability that the Malay entrepreneurs owe to themselves, their family and the community; as the main factor that lead them to initiate own venture. They want to be able to take part in developing their own self, their family members, and the Malay community. This sense of responsibility is partly created from their belief in Islam. Since Islam is a religion that covers everything in life, they want to make sure that the job also adheres to the Islamic rules and regulations.

Many Malay families in the area came from poor families. However, they wanted more for their children. As a result, business is calculated as one of the solution to their problems, not by working for others. The success of providing the best to their children is the most satisfaction that one can achieve. Furthermore, the Malay entrepreneurs seem to be looking for challenging environment that can steer their self-development. Therefore, the financial security and personal satisfaction are considered as another two important factors that influenced Malay entrepreneurs to start up own ventures. 


\section{REFERENCES}

1. Abdul Halim Yusoff. (1998). Pembiayaan Masalah Utama IKS. Berita Harian, 1 Ekonomi.

2. Herron, Lanny \& Sapienza, Harry J. (1992) The entrepreneur and the initiation of new venture activities. Entrepreneurship: Theory and Practice, 49-55

3. Het Financieele Dagblad (English). (2002) Start-ups aim for quality not size. October 9: p12

4. Hj Ismail \& A. Zaki (1998). Unpublished Ph.D. Thesis. Small and Medium Scale Industries (SMIs) in Malaysia: A Study of Selected Bumiputra SMIs in the Food Industry with emphasis on Public Policy Management and Markets. University of Bristol, UK. 186-190

5. Hofer, Charles W., \& Sandberg, William R. (1987). Improving new venture performance: Some guidelines for success. American Journal of Small Business, 12(1), 11-25. (From ABI/INFORM, Abstract No. 00382475).

6. MAPEN II, (2001) Laporan, Majlis Perundingan Ekonomi Negara Kedua; Dasar Pembangunan Wawasan 2001-2002, 31 January 2001

7. McKay, Ruth. (2001) Women entrepreneurs: moving beyond family and flexibility. International Journal of Entrepreneurial Behavior and Research, Volume 7 Number 4. New York: MCB University Press. 148-165

8. McKinnis, McNamara, Kuczek, \& Salvendy, (2001) The instructional Benefits from Faculty Participation in Industrial Outreach, Journal of Engineering Education, pg 430-434, Purdue University.

9. Scott, Gray. (2002). Entrepreneur's Handbook: Census shows majority of start ups don't borrow money. The Business Press/California, August 26: p17

10. Seventh Malaysia Plan 1996-2000. (1996) Kuala Lumpur: Economic Planning Unit, Prime Minister's Department.

11. Shaver, Kelly G. \& Scott, Linda R. (1991) Person, process, choice: The psychology of new venture creation. Entrepreneurship: Theory and Practice, 23-45

12. Wang, S.K. (1999). Unpublished Master Thesis. A study on Motivation to Start Up A Business Among Chinese Entrepreneurs. UUM Graduate School

13. Yeb Puteh, (1985), Keusahawanan, Kuala Lumpur; Dewan Bahasa dan Pustaka

14. Zimmerer, Thomas W. \& Scarborough, Norman M. (1996). Entrepreneurship and the new venture performance. New Jersey: Prentice Hall 